Вісник Дніпропетровського університету. Серія: Геологія, географія

Vìsnik Dnìpropetrovs'kogo unìversitetu. Serîa: Geologîa, geographîa

Dnipropetrovsk University bulletin. Series: Geology, geography

Dnipropetr. Univ. Bull. Ser.: Geol., geogr. 2015. 23(1), 17-23. doi: $10.15421 / 111502$

ISSN 2313-2159 print

ISSN 2409-9864 online

http://geology-dnu.dp.ua

УДК 556.491:622

\title{
Моніторинг земель та стану геологічного середовища балки Свпаторійської (Дніпропетровськ)
}

\author{
Л.Д. Богаченко*, Л.І. Осадча*, Т.Д. Прокопенко**, Т.В. Сібуль* \\ *Дніпропетровський національний університет імені Олеся Гончара \\ **Національний гірничий університет, Дніпропетровськ
}

\begin{abstract}
Проаналізовано стан земель та геологічного середовища Свпаторійської балки, визначено негативні інженерно-геологічні процеси і явища на території дослідження. Доведено можливість розвитку на схилах площинної і лінійної ерозій, яроутворення та зсувних процесів.

Ключові слова: моніторинг земель, природно-техногенні фактори, небезпечні інженерногеологічні процеси, захист територій.
\end{abstract}

\section{Monitoring of the land and geological environment condition in the Eupatorijska arroyo in Dnipropetrovsk}

\author{
L.D. Bogachenko*, L.I. Osadcha*, T.D. Prokopenko**, T.V. Sibul* \\ *Oles Honchar Dnipropetrovsk National University, Dnipropetrovs \\ * *National Mining University, Dnepropetrovsk
}

The article analyzes the condition of the land and the geological environment in the Eupatorijska arroyo, engineering-geological estimation of the territory of the arroyo is carried out, negative engineering-geological processes and phenomena are defined. It was found that due to the negative technogenic impact in conjunction with natural and climatic factors, the slopes under study can be considered as those under the risk of landslides and therefore are in need of engineering protection.

Key words: land monitoring, natural and technogenic factors, dangerous engineering and geological processes, the protection of territories.

Дніпропетровський національний університет імені Олеся Гончара, просп. Гагаріна, 72, Дніпропетровськ, 49010, Україна.

Oles Honchar Dnipropetrovsk National University, pr. Gagarina, 72, Dnipropetrovsk, 49010, Ukraine.

Tel.: +38-097-219-08-00. E-mail lila1809@mail.ru 
Вступ. Мета моніторингу стану земель та геологічного середовища вивчення природних умов території і впливу антропогенного навантаження для своєчасного виявлення змін та запобігання або усунення негативних наслідків, прогнозування змін інженерно-геологічних умов під впливом природнотехногенних факторів; розробка оціночних рекомендацій захисту території від небезпечних геологічних процесів і явищ.

Постановка проблеми. Територія правобережжя Дніпропетровська знаходиться на ділянці вододільного плато, «порізаного» ярово-балковою мережею. Такий рельєф спричиняє обвально-зсувні процеси, у результаті яких порушується природне залягання гірських порід, руйнується й змінюється морфологія схилів балок та ярів, формується специфічний зсувний рельєф, деформуються i руйнуються техногенні об'єкти. Унаслідок техногенної активізації небезпечних процесів постійно погіршується здатність геоморфосистем виконувати інженерні й екологічні функції [3].

На інтенсивність небезпечних процесів впливають природні (геоморфологія, геологія, тектоніка, клімат) і техногенні (інженерна діяльність людини) фактори [5]. Так, забудова верхньої частини лівого схилу Євпаторійської балки багатоповерховими будинками житлового масиву «Сокіл-2» у 1983 р. спричинила зсув, у результаті якого було зруйновано будинки приватного сектора по вул. Свпаторійській та зміщено дорожнє полотно $[1 ; 2 ; 4 ; 11]$.

У зв'язку з цим актуальне подальше вивчення теоретико-методологічних основ дослідження небезпечних процесів на території міста. Такими дослідженнями $є$ моніторинг стану земель і геологічного середовища [6;10].

Викладення основного матеріалу. Для виконання поставлених завдань проведено збір і систематизацію матеріалу вишукувань на досліджуваній територї та рекогносцирувальне обстеження балки.

У межах досліджуваної території балки, починаючи із 1965 р. по теперішній час, різні проектно-дослідні й дослідні організації виконували інженерно-геологічні розвідки для проектування й будівництва об'єктів цивільного і промислового призначення

У геоморфологічному відношенні досліджувана територія Євпаторійської балки розташована в межах терасованого вододільного схилу правого берега Дніпра, глибоко й інтенсивно «порізаного» ярово-балковою мережею, у південній частині міста між Тунельною та Відлогою балками.

Євпаторійська балка сформована в результаті тривалих екзогенних процесів кінця неогену - початку четвертинного періоду. Балка починається на вододільному плато і закінчується на заплаві Дніпра. Форма балки у верхів 'і $\mathrm{U}$-подібна, середня й нижня частини трапецеїдальні. Довжина становить $2000-$ 2100 м; форма асиметрична: лівий схил більш пологий, а правий крутий. Ширина балки у верхній частині приблизно $450-900$ м, $25-120$ м - у нижній. Глибина врізу балки змінюється від 35,0 - 40,0 м біля верхів'я до 3 - 5 м в ії усті.

У межах досліджуваної території виділяють такі геоморфологічні елементи верхів'я, правий і лівий схили балки, ускладнені ярово-балковою мережею, дно балки.

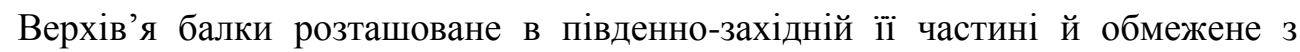
півночі вул.Панікахи та бульваром Слави; із північного заходу - проспектом Праці. Ширина верхів'я балки по верху - від 300 м до 550 м, по низу - від 30 м до 100 м. Борти від крутопадаючих до субвертикальних, інтенсивно «порізані» яружною 
мережею і вимоїнами. Субвертикальні борти не задерновані й оголюють корінні лесові грунти. Крутопадаючі схили задерновані, інтенсивно порослі деревинночагарниковою рослинністю. На схилах - відвали побутового сміття. На верхів балки зафіксовано ерозійно-зсувні процеси. Абсолютні відмітки денної поверхні верхів'я балки становлять 135,0 - 145,0 м (Балтійська система висот).

У верхів'я балки врізаються три відроги: північний, західний і південнозахідний.

Правий борт балки ускладнений ярами й трьома відрогами 3 ярами. Ухил правого борту змінюється від пологого (від 5 до $\left.15^{\circ}\right)$ до крутопадаючого $\left(30-45^{\circ}\right)$, на окремих ділянках штучно терасований. Тераси висотою $2-2,5$ м, шириною до 2 м, задерновані й засаджені захисною лісосмугою. У цілому схил задернований $\mathrm{i}$ поріс деревинно-чагарниковою рослинністю. Місцями наявні смітники побутового й будівельного сміття.

Абсолютні відмітки поверхні правого борту від його верхів'я до устя змінюються від 145,0 м до 90,0 м.

У південній частині в правий схил балки урізаються шість ярів довжиною $100-240$ м, шириною 15 - 50 м. Глибина ярів $-8-30$ м, що відповідає базису ерозії. Борти від крутопадаючих до субвертикальних, оголюють корінні лесові й делювіальні грунти, «порізані» вимоїнами, відбуваються активні зсувні процеси. Верхів'я ярів зайняті під городи. Дно ярів поросло деревинно-чагарниковою, місцями болотною рослинністю. У теперішній час відроги ярів засипають будівельно-побутовим сміттям.

Лівий борт балки ускладнений численними вимоїнами, що переходять в яри V-подібної форми із крутопадаючими бортами, задерновані, порослі деревною рослинністю. Місцями в бортах ярів оголюються лесові грунти. Глибина урізання ярів $-1-8$ м. Лівий схил крутопадаючий, під кутом $25-30^{\circ}$, у деяких місцях терасований. Ширина терас $-2-3$ м, висота 1,5 м. До устя балки лівий схил виположується до $4-6^{\circ}$. Схил задернований, порослий деревинно-чагарниковою рослинністю.

Абсолютні відмітки поверхні лівого борту від його верхів'я до устя змінюються від 135,0 м до 65,0 м.

У створі вул. Среванської в лівий борт балки урізається відріг довжиною $\sim 100$ м коритоподібної форми, глибиною урізання $5-7$ м, шириною $8-12$ м (по дну), шириною по бортах - $50-60$ м; кут бортів - $45-50^{\circ}$. Борти й дно відрогу задерновані, верхів'я засипане, обладнане підпірною стінкою.

Дно балки складної форми - від асиметричної коритоподібної до каньйоноподібної, виположується до устя балки.

Біля верхів'я та в центральній частині балки дно асиметричне, коритоподібної форми. Ширина дна - 50 - 70 м. Лівий схил більш крутий, терасований, слабкозадернований, порослий деревинно-чагарниковою рослинністю. Загальний ухил $-15-20^{\circ}$. Правий схил виположений, кут ухилу від 6 $-8^{\circ}$ до $10^{\circ}$, задернований і укріплений уздовж терас лісопосадкою. На окремих ділянках дно балки каньйоноподібної форми, глибиною урізання $6-7$ м, шириною 15 - 20 м, борти складаються із балкового делювію (суглинки чорного кольору). На бортах відбуваються ерозійні процеси у вигляді вимоїн і мікроярів.

Абсолютні відмітки поверхні дна балки від 95,0 - 105,0 м (на верхів’ї) до $63,0-65,0$ м (в усті балки). 
На дні балки утворилося озеро діаметром 10 - 12 м. Із озера витікає струмок шириною від $0,5-1,5$ м, глибиною від $0,05-0,3$ м. У долині струмка відбувається акумулятивний процес - накопичення балкового делювію. Борти струмка від пологих до крутопадаючих, висотою від 0,5 м до $3-4$ м.

Місцями на дно балки скидають будівельне і побутове сміття, що перешкоджає розвантаженню струмка.

На досліджуваній території відбуваються такі несприятливі процеси і явища:

- наявність у геологічній будові балки нестійких, субвертикальних i крутопадаючих схилів, складених лесовими грунтами;

- просочування грунтових вод біля підніжжя схилів;

- інтенсивні витоки $з$ комунікацій, які підвищують рівень грунтових вод, призводять до замочування лесових грунтів і погіршення їх фізико-механічних властивостей, а отже до появи на стінах будівель тріщин деформаційного характеру;

- повсюдні звалища побутового сміття, що забруднюють грунтові води, перешкоджають поверхневому стоку вод, акумулюють вологу, призводять до замочування грунтів, а отже, зниження стійкості схилів;

- активні ерозійні й зсувні процеси, що проявляються на незадернованих схилах балки, на схилах її відрогів і ярів.

У геоструктурному відношенні територія Дніпропетровська знаходиться на 3'єднанні двох великих структур - Українського кристалічного масиву й ДніпровоДонецької западини.

Територія Євпаторійської балки розташована в межах крайової частини Українського кристалічного масиву, що належить до нагірного неотектонічного блока.

Конфігурацію балки визначено тектонічною зоною субширотного напрямку. Геологічний масив складають кора вивітрювання скельних порід і осадові відклади палеогенового, неогенового та четвертинного періоду.

У межах досліджуваної території балки розвинута кора вивітрювання (PZKZ) скельних порід, покрівля яких залягає від денної поверхні на глибині $70-80$ м біля верхів'я балки до 25,0 - 26,0 м в її усті.

Ерозійні депресії у кристалічному фундаменті заповнені континентальними (озерно-річковими) відкладами бучакської світи палеогену $\left(\mathrm{P}_{2}{ }^{\mathrm{bc}}\right)$ (буровуглисті глини та буре вугілля).

Неогенові відклади - полтавська світа $\left(\mathrm{N}_{1}{ }^{\mathrm{pl}}\right)$ - сірі глини і світло-жовті, білі кварцеві піски. На схилах балки неогенові відклади перекриті суглинками i червоно-бурими глинами нижньочетвертинного періоду (d I mr), які не мають чіткої межі. Поширення нижньочетвертинних відкладів повсюдне, за винятком придонної частини балки, де вони розмиті.

В умовах Дніпропетровська глибинність розвитку екзогенних геологічних процесів безпосередньо залежить від геологічної будови і геоморфологічного розчленування території і належить до верхньої 10 - 30-метрової товщі чохла четвертинних відкладів, яка складається з нижнього, середнього, верхнього відділів та сучасних відкладів.

Четвертинні відклади лесового комплексу плащеподібно перекривають схил у верхній і середній його частинах і виклинюються в дно балки, представлені 
шарами суглинків та супісків елювіально-делювіального (ed), еоловоделювіального (vd) генезисів й алювіальними (a) пісками.

Відповідно до геологічної структури досліджувана територія належить до гідрогеологічного району Українського кристалічного масиву.

У межах Євпаторійської балки зафіксовано один водоносний комплекс, який складається із двох різновікових водоносних горизонтів: четвертинний горизонт поширений у лесових, алювіально-делювіальних, алювіальних відкладах і балковому делювії; неогеновий - у пісках полтавської світи. Обидва горизонти безнапірні, тому що не мають між собою витриманого вододільного шару, який би був водотривом. Перетікання верхнього горизонту в нижній відбувається через ділянки, де щільні грунти відсутні, - «гідрогеологічні вікна».

Водоносний горизонт четвертинних відкладів зафіксований: біля верхів'я балки на глибинах 7,0 - 8,0 м (абс. відм. 138,0 - 145,0 м); на лівому схилі балки від 9,0 м до 14,0 м (абс. відм. 91,0 - 132,0 м); на правому схилі балки від 9,0 м до 13,0 м (абс. відм. 126,0 - 138,0 м), у південно-східній частині схилу горизонт відсутній; на дні балки від нуля до $1,0-2,0$ м. Коефіцієнти фільтрації грунтів зони аерації і водовмісних грунтів змінюються від 0,2 м/добу до 0,6 м/добу.

Відносними водонепрохідними шарами $\epsilon$ локально щільні суглинки завадівського та суглинки і глини мартоношського горизонтів. Потужність водоносного горизонту не витримана й тісно взаємопов'язана з глибиною залягання водотриву.

Режим водоносного горизонту четвертинних відкладів порушений і тісно пов'язаний із кількістю води, що поповнює його. Живлення він одержує за рахунок інфільтрації атмосферних опадів, витоків із підземних каналізаційних мереж із боку вищерозташованих забудованих територій мікрорайону «Сокіл», промислових підприємств та індивідуальної забудови вздовж лівого схилу балки. Розвантажується горизонт в дно балки, перетікає в нижній горизонт неогенових відкладів, а потім у Дніпро.

За хімічним складом вода водоносного горизонту четвертинних лесових відкладів є гідрокарбонатно-сульфатна із мінералізацією до 1 г/дм³

Водоносний горизонт неогенових відкладів у придонній частині схилів, де четвертинний горизонт відсутній, - перший від денної поверхні, а у верхній частині схилів перебуває під четвертинним водоносним горизонтом і є другий від денної поверхні.

Водовмісними породами горизонту є піщані відклади неогену, які мають коефіцієнт фільтрації 1,0-1,2 м/добу.

На території балки глибина залягання рівня горизонту неогенових відкладів на лівому схилі становить 45,0 - 50,0 м.

Буровугільні глини та каоліни мають більш низьку водопроникність $\left(K_{\phi}=0,06\right.$ і 0,085 м/добу), ніж вище- і нижчезалягаючі грунти, тому вони - відносні водотриви. 3 г/дм ${ }^{3}$.

За хімічним складом вода переважно гідрокарбонатна із мінералізацією 1 -

Горизонт поповнює запаси води за рахунок інфільтрації атмосферних опадів і перетікання підземних вод шляхом вертикальної фільтрації із водоносного горизонту четвертинних відкладів на схилах балки та із струмка через делювіальні відклади. Розвантаження горизонту відбувається в Дніпро. 
За природними умовами територія Євпаторійської балки розташована в зоні змінного зволоження, складена фільтраційно-анізотропними лесовими відкладами.

Аналіз матеріалів досліджень минулих років (1965 - 1980) показав, що інтенсивна забудова верхніх частин схилів балки висотними будівлями призвела до збільшення витоків води в грунти із підземних комунікацій. Інженерна діяльність людини (прокладення доріг, терасування денної поверхні - зрізання та підсипання ділянок, побудова гаражів, облаштування городів, неорганізовані сміттєзвалища) призвела до проникнення атмосферних опадів у грунти схилів. Вищенаведені фактори спричинили підйоми рівня підземних вод із середньою швидкістю на окремих щільнозабудованих територіях до 1,0 - 1,2 м/рік.

На основі режимних спостережень за рівнем підземних вод (1980 - 2000) установлено, що швидкість підйому рівня підземних вод поступово зменшувалась, а за останні роки стабілізувалася і не перевищує 0,1 м/рік. Це перш за все пов'язано зі зменшенням обсягів будівництва, а на верхніх ділянках схилів - із відтоком води горизонту із зсувних ділянок схилів, які сприяють швидшому відтоку води через «вікна» розкритих грунтів. Однак, враховуючи незадовільний характер експлуатації підземних комунікацій на забудованих територіях, можливий підйом рівня підземних вод до значень, зафіксованих раніше, і більших.

За геолого-гідрогеологічними умовами і швидкістю підйому рівня підземних вод ділянки верхів’я та схилів балки належать до III типу територій за потенційним підтопленням.

Рівень підземних вод в усті балки знаходиться на глибинах від 0,2 м до 2,0 м, тому ця ділянка належить до категорії природно і постійно підтоплюваних територій. Підтоплення донної частини балки пов'язане зі збільшенням надходження атмосферних і стічних вод у дно балки (утворення джерел у ярах i зсувних ділянках - дренування водоносного горизонту четвертинних відкладів), а також забудовою нижчерозташованої території житлового масиву «Перемога» висотними будинками на пальових фундаментах, що призвело до погіршення дренування води через баражний ефект.

У зв'язку з підвищенням вологості лесових грунтів через причини, наведені вище, які характеризують ці грунти як водонетривкі, пухкі, легкорозмочувані, здатні до прояву просідних властивостей, у них можуть погіршитися показники фізико-механічних властивостей, знизитися характеристики деформованості й міцності [7 - 9].

Просідність грунтів за природного тиску безпосередньо залежить від потужності просідних грунтів. Потужність просідних лесових грунтів зростає від нижньої частини схилів балки, де вони виклинюються, до вододільних ділянок, де їх потужність максимальна.

Просідність лесових грунтів (за матеріалами минулих років) вивчали на всіх ділянках забудови лабораторними методами. Сумарна просідність лесової товщі за природного тиску змінюється від 0 до $50-60$ см.

Досліджувані схили балки за просідністю належать до двох типів грунтових умов - першого і другого, а на підтоплених ділянках на дні балки просідні грунти відсутні.

Лесові грунти $є$ фільтраційно-анізотропні: у вертикальному напрямку вони більш водопроникні, ніж у горизонтальному. У зв'язку із цим у фільтраційному 
потоці виникає гідродинамічний тиск підземних вод, а також збільшується вага грунтів - додаткова механічна сила, прикладена до схилу.

Висновки. На обох схилах балки за рахунок природних і техногенних факторів, основними з яких $є$ обводнювання лесових грунтів, додатковий тиск на грунти схилів від нових забудов, неминуче можуть проявлятись негативні інженерно-геологічні процеси і явища.

Оцінивши геолого-геоморфологічні i гідрогеологічні особливості досліджуваної території балки (круті ділянки схилів, повсюдне поширення пухких водонестійких лесових грунтів, наявність насипних грунтів у різних частинах схилів, подальше насичення грунтів схилу водою), можна й надалі прогнозувати розвиток на схилах площинної і лінійної ерозії, яроутворення та зсувних процесів.

\section{Бібліографічні посилання}

1. DBN A.2.1-1-2008. Inzenerni vishukuvanija dlja budivnitstva [Text] - K.: Minregionbyd, 2008. - P. 72 (in Ukrainian).

2. DBN B.1.1-3-97 Inzenernij zahist teritorii, budinkiv i sporud vid zsuviv i obvaliv [Text]: - K.: Minregionbyd, 2006. - P. 83 (in Ukrainian).

3. Dowd, R.M. Groundwater monitoring [Text]/ R.M. Dowd// Environ. Sei. and Technol. - 1985 Vol. 19. - № 6. - P. 485-498.

4. DSTY B V.2.1-2-96. Gruti. Klasifikatsija [Text]/ (DERZSTANDART 2510082) - K.: Minregionbyd, 2006. - P. 98 (in Ukrainian).

5. Emeljanova, O.P. Osnovni zakonomirnosti zsuvnih protsesiv [Text]/ O.P.Emeljanova. - M.: Nedra, 1972. - P. 346 (in Ukrainian).

6. Latkovich, V.J. Groundwater monitoring system [Text]/ V.J. Latkovich// Proc. and Inf. Comm. Hydrol. Res. TNO. - 1983. - № 31. - P. 538-545.

7. Lomtadze, B.D. Inzenerna geologija. Inzenerna geodinamika [Text]/ B.D. Lomtadze. - M.: Nedra, 1977. - P. 423 (in Russian).

8. Rekomendatsiji po inzenerno-geologithnim doslidzenijam $\mathrm{v}$ rajonah rozvitku zsuviv [Text] - M.: Nedra, 1984. - P. 94 (in Ukrainian).

9. Rekomendatsiji po kilkisnij otsintstij stijkostisi zsuvnih protsesiv [Text]. - M.: Nedra, 1984. - P. 132 (in Ukrainian).

10. Wishmeier, W.H. Predicting rainfall erosion losses from cropland east of Rocky Mountains [Text]/ W.H. Wishmeier, D.D.Smith// Argic. Handbook. - 1965. № 282. - P. 143-151.

11. Zvit pro inzenerno-tehnichni vishukuvanija dlja proektovanogo budivnitstva bagatofunktsionalnoji budivli v rajoni $\mathrm{z} / \mathrm{m}$ «Sokil» u m. Dnipropetrovsku [Text]/ DP «DniproGIINTIZ». - DP., 2006. - 185 p (in Ukrainian).

Надійшла до редколегії 27.02.2015 